\title{
フレームレス原子吸光分析法による岩石・土じょう 試料中の微量水銀の定量
}

\author{
加藤 甲壬, 安 藤 厚*, 岸本 俊彦**
}

(1972 年 2 月 9 日受理)

\begin{abstract}
加熱によって容易に原子蒸気化できる水銀の特性を利用し，岩石・土じょう試料中の微量水銀分析用 のフレームレス原子吸光分析装置を作製し, 詳しく測定条件の検討を行なった. 試料中の水銀は $500^{\circ} \mathrm{C}$ で 3 分間加熱することによって完全に単原子蒸気化する. 加熱によって放出された気体成分を金線捕集 部を通過させ，水銀のみをアマルガムとして金線上に固定し，他の妨害気体と分離する.アマルガム部 を加熱し，発生する水銀蒸気を吸収せル中に導いて原子吸光度を測定する。本装置により岩石・土じょ う試料中の総水銀を定量範囲 1 1 $1000 \mathrm{ng}$ ，变動係数 $5 \%$ 程度，1 $\mathrm{g}$ 試料を用いて検出限度は $1 \mathrm{ng}$ ， た 1 試料の分析所要時間は 6 分以内であった.
\end{abstract}

1 緒言

岩石・土じょう試料中の水銀含量は特殊な場合を除い て，ほぼ 5〜500 ng 程度である1).したがって分析方法 は $10^{-9} \mathrm{~g}(\mathrm{ng})$ オーダーの検出限度をもつ必要がある。 従来用いられてきた 溶媒抽出 ジチゾン 吸光光度法では $10^{-6} \sim 10^{-7} \mathrm{~g}^{2) 3)}$ が限度である. 試料溶液を直接フレー ム導入する通常の原子吸光分析法では，検出限度は $5 \times 10^{-7} \mathrm{~g}$ 程度 ${ }^{4)}$ でありあまり感度良好とはい光ない。

Brandenberger $ら^{5)}$ は溶液中の水銀を銅線上にアマル ガムとして捕集したのち，吸収セル中でアマルガムに電 流を通じて加熱分解し，遊離した水銀蒸気の原子吸光度 を測定する方法を，Hatch' ${ }^{6)}$ らは，酸分解して得られた 試料溶液中の水銀を硫酸第一スズで金属状態に還元した のち, 空気を通じて追い出し, 吸収セル中に導いて原子 吸光度を測定する方法を検討している．これらの方法に よって 0.2〜0.3 ng の水銀を検出することができる.

しかし，これらの方法では固体試料を溶液化しなければ ならない。

分析試料を固体のま直接加熱し，発生する水銀蒸気 をチャンバーや吸収セルに導いて原子吸光分析する方法 は James ら7, Barringer8), Williston ら9)によって主と して地球化学探鉱に用いる目的で研究された. Vaughn ら ${ }^{10) 11)}$ は金を水銀の捕集トラップとして用いた固体加熱

* 地質調查所 $:$ 神奈川県川崎市高津区久本

** 日本ジャーレル・アッシュ株式会社：京都市代見区 下鳥羽浄春ヶ前町
方式の最初の実用性のある装置を作製した。

著者らも独自に固体加熱方式のフレームレス原子吸光 分析装置を試作し，従来あまり敄告のなかった妨害成分 の分離，測定条件，再現性なぞについて詳しい検討を行 ない，感度，精度および分析能率などの諸点について良 好な結果が得られたので報告する。なお，この研究の一 部は加藤 ${ }^{22}$ によって報告された.

この装置を使用することによって, 試料の酸分解など の煩雑な操作を必要とせず，固体粉末試料をそのまま加 熱してただちに検出限度 $1 \mathrm{ng}$ までの水銀を定量するこ とができる. 1 試料の分析所要時間は 6 分以内である.

\section{2 測定原理}

Fig. 1 亿測定系統を示す. 岩石・土じょうなどの粉末 試料（100×ッシュ以下）を磁製ボートに入れたのち分 解师中の石英管中へそう入する. 分解炉中の石英管の中 央部は試料の分解に適した温度, たとえば岩石・土じょ う試料の場合は $500^{\circ} \mathrm{C}$ の定温度に加熱しておく. 試料 中の水銀化合物は 3 分以内にほとえど完全に解離して単 原子の水銀蒸気となる. 同時に岩石中の水分，硫化物の 分解に基づく亜硫酸ガス，炭酸塩や有機物の分解に基ゔ く二酸化炭素や有機物気体などが発生する. 分解炉中の 石英管の一端は試料そう入口として開口し，他の一端は 水銀捕集用の金線トラップ，さらに吸収セルを経て吸引 ポンプに接続されている. 試料の加熱分解中は吸引ポン プで $1 \mathrm{l} / \mathrm{min}$ の空気を流通させておく. 加熱によって 試料より放出された分解生成気体が金線捕集トラップを 
通過する際，水銀は 金とアマルガムを生成して 捕集さ れ，その他の気体は系外へ排気される. 分解完了後試料 ボートを外へ取り出し排気ポンプを止める．次に水銀捕 集部の $500^{\circ} \mathrm{G}$ に予熱された加熱炉を左へ動かして金線 アマルガムを加熱する．金線部に装着された熱電対温度 計の読みが定温度（約 $400^{\circ} \mathrm{C}$ ) に達したとき，ただちに 排気ポンプを作動させ，アマルガムが分解して発生した 水銀蒸気を吸収管中に導き，原子吸光度を測定する.

\section{3 装置および試薬}

\section{1 装}

装置は Fig. 1 亿示すように, 試料分解部, 水銀捕集 部, 測定部からなっている.

3.1.1 試料分解部 内径 $17 \mathrm{~mm}$, 長さ $20 \mathrm{~mm}$ の 透明石英管とこれを加熱する筒型電気炉からなる．石英 管の一端は試料そう入口として開口し，他の一端は水銀 捕集部につながる. 試料分解用の電気炉は熱電対温度計 および自動温度調節器付き. 粉末試料を入れて加熱する 磁製ボートは $70 \mathrm{~mm} \times 12 \mathrm{~mm} \times 9 \mathrm{~mm}$, 容量 $2 \mathrm{ml}$, 岩 石・土じょう粉末約 $1 \mathrm{~g}$ がはいる.

3.1.2 水銀捕集部 金線の水銀捕集トラップを内蔵 する内径 $5 \mathrm{~mm}$ の石英 U 字管と，アマルガム分解用の 電気炉，捕集部冷却用ブロワーからなる. 水銀捕集トラ ップは太さ 80 ミクロンの純金線約 $1.5 \mathrm{~g}$ をネット状に まるめたフィルター（約 $30 \mathrm{~mm} \times 5 \mathrm{~mm} \phi$ ） である. 水
銀の 捕集中は 金線捕集部をブロワーで泠却する．捕集 後, アマルガム分解用の電気炉をレールに沿って左へ動 かし，捕集トラップを加熱する. 加熱操作中はブロワー は自動的に停止し, 分解操作完了後, 電気炉を右へ移動 させるとふたたび冷却用ブロワーが作動し，次の操作に 備えるようになっている. 電気炉は試料分解炉と同じく 熱電対温度計および自動温度調節器付き.また金線捕集 部には特に熱電対を装置し，直接金線の温度を観察でき るようになっている.

3.1.3 測定部 測定波長は $2537 \AA$ ，光源は日本シ ヤーレル・アッシュ社 No. 710130 中空陰極ランプ, 使 用電流 $3 \mathrm{~mA}$. モノクロメーターは日本ジャール・アッ シュ社 $0.25 \mathrm{~m}$ エバート型, 使用スリット幅は $0.3 \mathrm{~mm}$. 光強度の測定は浜松テレビ R 106 光電子增倍管. 増幅器 は対数変換増幅回路を用いて, 最高 10 倍まで連続的に 拡大することができる，光路中におかれた吸収セルは内 径 $17 \mathrm{~mm}$, 長さ $220 \mathrm{~mm}$ 石英製. 吸光シグナルは吸光 度変換が行なわれたのち記録計に記録される。記録計は フルスケール $1 \mathrm{mV}$ ，チャート・スピードは $20 \mathrm{~mm} /$ min. 記録計上のピークの高さを読み取り検量線を作成 する.

測定部を通過した気体は水銀トラップと流量計を経て 吸引ポンプによって排気される. 水銀蒸気は健康上有害 なうえ，排気された水銀蒸気が室内の空気を污染し，測 定を妨げることのないように，水銀トラップには金線， 銅粒と活性炭を使用した特殊なつィルターを用いて水銀

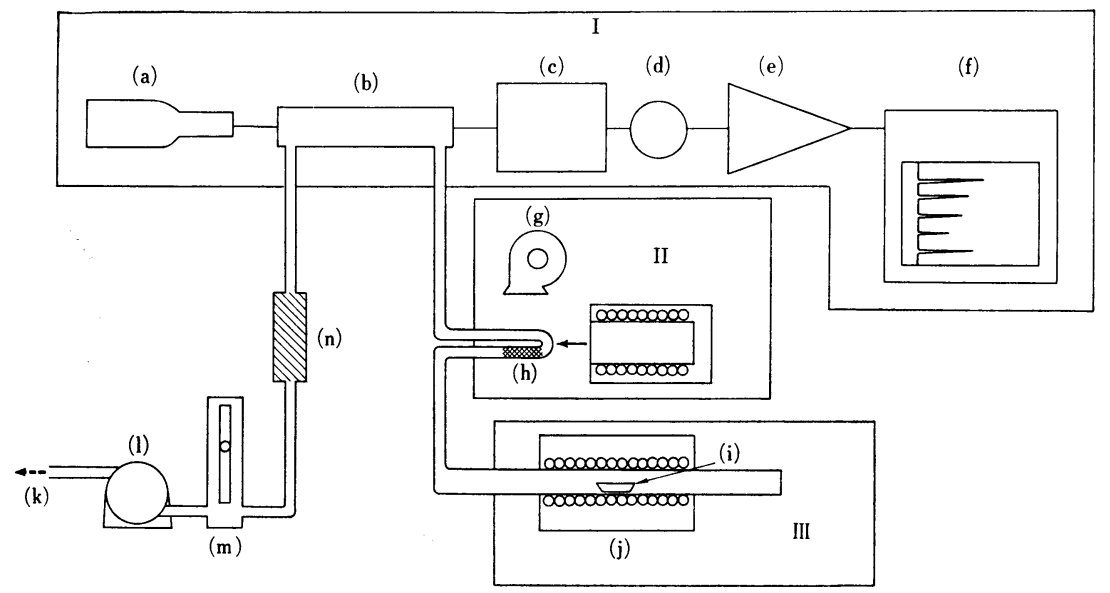

Fig. 1 Schematic diagram of apparatus

I : Mercury-vapor detector part, (a) Mercury H. C. lamp, (b) Absorption cell, (c) Monochrometor (2537 $\AA$ ), (d) Photodetector, (e) Amplifier, (f) Recorder; II : Mercury trap part, (g) Cooling blower, (h) Gold wire; III : Sample decomposition part, (i) Sample boat, (j) Decomposition furnace; (k) Exhaust, (I) Suction pump, (m) Flow meter, (n) Mercury trap 
を完全に分離したのち排気するようになっている，吸引 用のダイヤフラムポンプと流量計の調節部によって流量 は $0 \sim 2 l / \mathrm{min}$ に調節できる.

\section{2 標準試料}

純度の高いけい砂粉末を電気炉中で $1000^{\circ} \mathrm{C}$ ，約 20 分加熱し，水銀化合物を完全に除去する．このけい砂を 標準試料の基郕とした．重量分析法により水銀含量の確 かめられた，しえ砂（大部分が硫化第二水銀）を適当量 ひょう量し，上記の基凨粉末で，めのう製遠心式ボール ミルを用いて混合希釈する操作をくりかえして標準試料 を調製した。実際の分析操作に対しては， $1 \mathrm{~g}$ 中に 100 ng の水銀を含有している標準試料が便利である．加熱 ボート中に入れる標準試料のひょう量值を変化させるこ とにより，容易に任意量の水銀のシグナルを得ることが できる.一方，分析試料のひょう量值も試料中の水銀含 量によって適宜調節すればよい。

比較のため, 塩化第二水銀を用いて上記の操作に従っ て，1 $\mathrm{g}$ 中に $100 \mathrm{ng}$ の水銀を含む標準試料を調製した. 両標準試料を用いて水銀のシグナルを測定した場合，両 者の差はほとんど認められなかった. しかし，著者らの 経験によると, 後者の塩化第二水銀試薬を用いて調製し た標準試料は，前者のしん砂を用いて作成した標準試料 に比べて，やや安定性に欠けるきらいがある。

\section{4 結果と考察}

\section{1 試料中の水銀の熱分解}

試料中の水銀化合物の熱分解を観察するため, 測定系 より水銀捕集用の金線フィルターを取り除き，吸引ポン プを作動させて一定量の空気 $(1 \mathrm{l} / \mathrm{min})$ を流通させ, 電 気炉で加熱されて生成した気体がそのまま吸収セルを通 過するようにする。

標準試料 $0.5 \mathrm{~g}(50 \mathrm{ng}$, 水銀) を入れた磁製ボートを 予熱された分解炉中にとう入し，経過時間に伴う水銀原 子吸光度の变化を測定した結果を Fig. 2 に示す. 分解 炉の予熱温度 $400^{\circ} \mathrm{C}$ の場合は試料のそう入後約 130 秒, $500^{\circ} \mathrm{C}$ の場合は 80 秒, $600^{\circ} \mathrm{C}$ の場合は 50 秒でほぼ水 銀化合物の蒸発分解が完了することがわかる. この過程 における実際の試料温度を測定するため, 分解炉の中央 にそう入した磁製ボートに熱電対の先端を装着し，そう 入後の経過時間に伴う温度の上昇を測定した. Fig. 3 の 結果より $400 ， 500,600^{\circ} \mathrm{C}$ にそれぞれ予熱された分解 炉中で，Fig. 2 で明らかとなった試料とう入後の水銀化 合物の 分解完了時における磁製ボートの温度はそれぞ れ，320，350，および $340^{\circ} \mathrm{C}$ であり, 試料中の水銀化

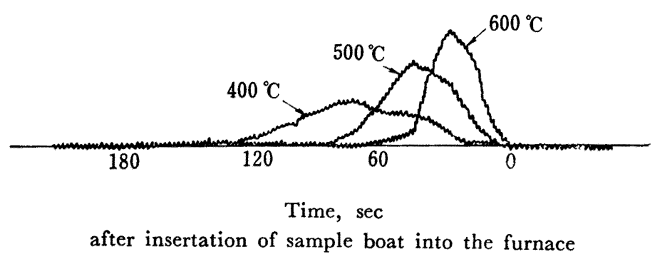

Fig. 2 Variation of absorbance with decomposition time

$0.5 \mathrm{~g}(100 \mathrm{ng} \mathrm{Hg} / \mathrm{g})$ of the standard sample is heated in the preheated electric furnace.

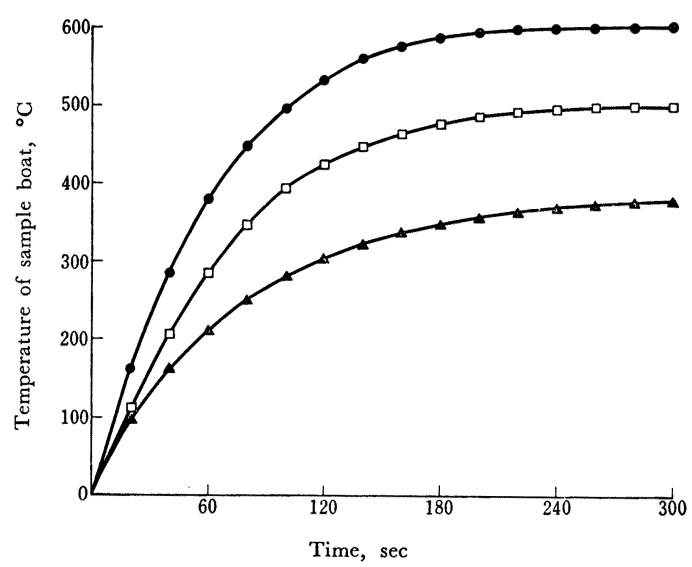

Fig. 3 Variation of the sample boat temperatures in the decomposition furnace

Preheated temperature of decomposition furnace : $-600^{\circ} \mathrm{C},-\square-500^{\circ} \mathrm{C},-\boldsymbol{\Delta}-400^{\circ} \mathrm{C}$

合物はほぼ $350^{\circ} \mathrm{G}$ までに完全に熱分解されて原子蒸気 化することがわかる.

標準試料のほか，実際の岩石・土じょう試料について 同様な検討を行なった結果，分解炉の予熱温度が 400〜 $600^{\circ} \mathrm{C}$ の場合，試料量が最大の $1 \mathrm{~g}$ の場合でも，試料そ う入後の水銀の放出速度はかなり大きく，ほぼ 2 3 分 で完了する. 以上の測定結果より 試料の分解条件とし $\tau$, 分解炉の 予熱温度 $500^{\circ} \mathrm{G}$ ，加熱時間は安全をみて 3 分として以下の実験を行なった。

\section{2 共存成分の影響と分離}

岩石・土じょうなどの粉末試料を加熱すると，試料中 の水分，悪硫酸ガス，有機物を含有する場合は有機物気 体を放出する．これらの気体は水銀共鳴スペクトル線を 吸収する. 特に水分は吸収セル中で小さな水滴を生じや すくスペクトル線を吸収または散乱し，偽吸収を生ず る.このような影響を除くため水銀捕集トラップを使用 
する. 実際の試料について水銀捕集トラップを用いない 場合と，使用した場合の吸収チャートを Fig. 4 に示し た.これは硫化鉱物を含んだ岩石試料を測定したもの で，水銀捕集トラップを用いないAでは水銀と妨害気体 の吸収は重なって現われる. 水銀捕集トラップを用いた B の場合は，トラップで水銀が捕集されるので，最初に 妨害気体のピークが現われる.これらの妨害気体を排気 したのち, トラップを加熱し放出される水銀のみのピー クが記録される．このように水銀捕集トラップを用いる ことによって妨害気体の影響から完全に分離することが できる.
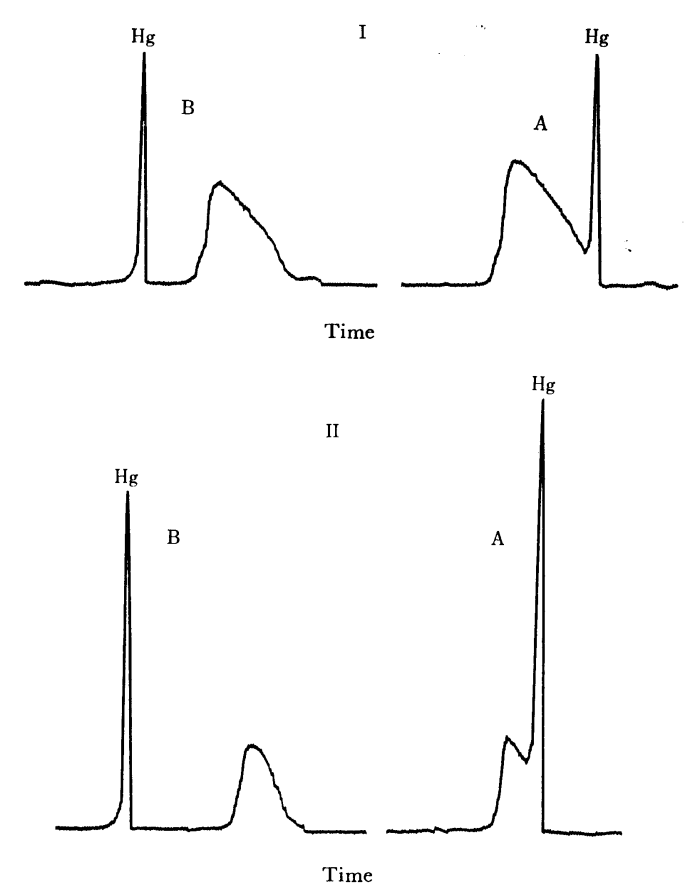

Fig. 4 Effect of diverse compounds on the absorbance

I : Soil sample; II : Rock sample; A : Without gold trap, peaks due to the mercury and the diverse compounds are overlapped somewhat. B : With gold trap, a peak due to the diverse compounds comes first, and the second peak due to the mercury is appeared by heating the trap.

試料中に含まれる水分の妨害について，ボートにはか りとった標準試料に純水を添加し，水銀測定值に及ぼす 影響を調べた. Fig. 5 に測定結果を示す. 分解炉で試料 を加熱すると，水銀捕集トラップ付近に水分の凝縮が現 われるが，通気時間の経過とともにしだいに外部へ排出 される.この間測定部のメーターに吸収が表示される

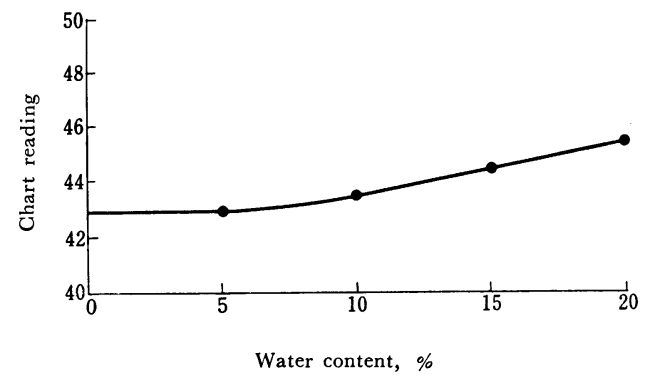

Fig. 5 Effect of water on absorbance Distilled water is added to each standard sample.

が，時間の経過にしたがってしだいにゼロ点にもどる. 分解炉から試料ボートを取り出すと, 他の妨害成分は 30 秒以内に吸收值がゼロにもどるが，水含量が高い場 合は, 水の含量に比例してゼロ点にもどる時間が長くな る.水分による吸収值がなくなったのち，水銀捕集部を 加熱し, 吸光度を測れば, 含水率 $10 \%$ 程度までは影響 がなく，15〜20\% では残留した水分でわずかに 正誤差 を生ずる.

\section{3 空気流通量}

2 で述べた全分析操作を行なら場合, 通過させる空気 の流量が吸光度に影響する. $50 \mathrm{ng}$ の水銀を含む標準試 料を用い, 空気流量を $0.4 \sim 2 l / \mathrm{min}$ の範囲で変化させ, 水銀の吸光度を測定した結果を Fig. 6 に示す. この装 置のディメンジョンでは, 空気流量 $1 \sim 1.2 \mathrm{l} / \mathrm{min}$ の条

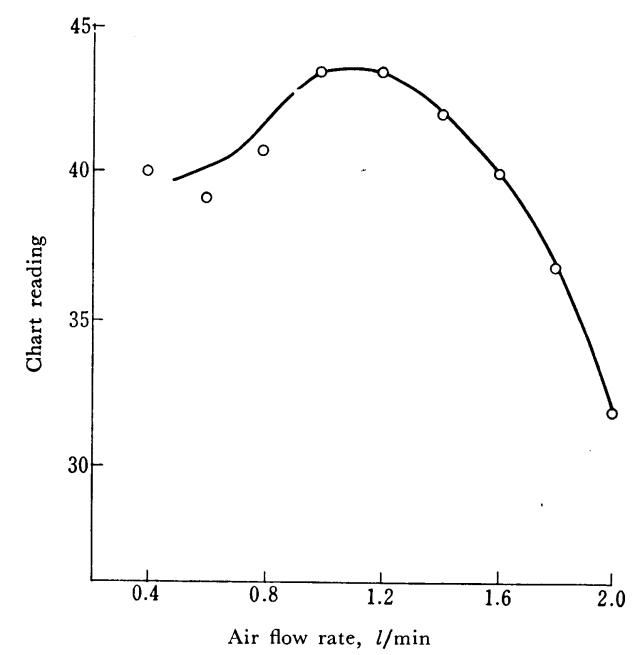

Fig. 6 Effect of air flow rates on absorbance

$0.5 \mathrm{~g}(100 \mathrm{ng} \mathrm{Hg} / \mathrm{g})$ of the standard sample was used for each measurement. 
件で最大吸光度が得られた。

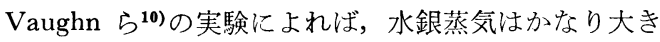
い流速でもほぼ完全に金に捕集される.したがって， Fig. 6 の測定結果は主として測定のあとの操作，すなわ ち，金一アマルガム部を加熱し，放出された 水銀蒸気を 吸収セルに導き，吸光度を測定する過程の通気量の影響 を示している．通気量があまり高いと希釈によって感度 が減少し，またあまり低すぎるとピークの立ち上がりが わるくなり，再現性も落ちる.

\section{4 金線充てん量}

水銀捕集部に充てんする金線の量と捕集される水銀量 の関係を検討した．標準試料を段階的にはかりとり，分 解炉で放出された水銀蒸気を，金線 1.0，1.5，2.0， $2.5 \mathrm{~g}$ を充てんした捕集トラップにそれぞれ集める. こ のアマルガムを加熱炉で $500^{\circ} \mathrm{C}, 60$ 秒加熱したのち空 気の流通を全開し吸光度を測定した. 結果を Fig. 7 に 示す. 水銀捕集部の金線量を $1.5 \mathrm{~g}$ にしたとき水銀量に 比例して吸光度は直線的に増加している. これに対して 充てえ量 $1.0 \mathrm{~g}$ の場合は水銀量の増加にともない吸光度 は低下する，その原因は金線接触面積が少ないため，特 に水銀高濃度の場合は完全に捕集しきれないためと考え られる. 金線を $2.0 \mathrm{~g}$ 以上に増加させると, 水銀量の増 加とともに金線量 $1.5 \mathrm{~g}$ の場合に比べて吸光度は低下し た.これは金線量が多くなると，加熱による金と水銀の 分解速度が小さくなるためと考えられる。

以上の実験結果から，100 ng までの水銀の定量には 金線 $1.5 \mathrm{~g}$ を充てんすることにした.

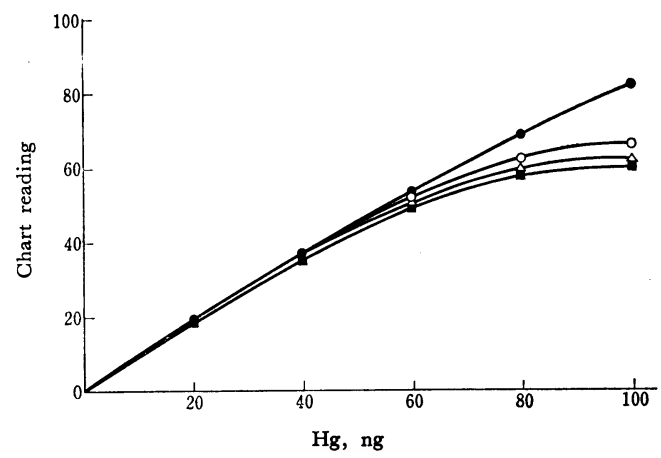

Fig. 7 Effect of amount of gold wire on working curves

Weight of gold : $-\square-1.0 \mathrm{~g},-\mathbf{-}-1.5 \mathrm{~g},-\mathrm{O}-2.0 \mathrm{~g}$, $-\triangle-2.5 \mathrm{~g}$

\section{5 金アマルカムの加熱条件}

$500 \mathrm{ng}$ の水銀を含む標準試料を加熱分解し，放出さ
れる水銀蒸気を金線上にアマルガムとして捕集する．こ の金アマルガムを用いて水銀の分解放出条件を検討し た．加熱炉の予熱温度と，炉にそう入後空気の流通を開 始するまでの時間を变化させて水銀の原子吸光度を測定 した結果を Table I に示した. Table I から加熱炉温 度 $450 \sim 600^{\circ} \mathrm{C}$ ，空気の 流通を開始するまでの時間 60 秒と，加熱温度 $600 \sim 700^{\circ} \mathrm{C}$ ，流通開始までの時間 30 秒，および $600^{\circ} \mathrm{C}$ で加熱し，30〜60 秒後に流通を開始 する測定条件の場合が最も感度のよいことがわかった。

Table I Heating condition for the decomposition of mercury on the gold trap wires

\begin{tabular}{ccc}
\hline $\begin{array}{c}\text { Furnace temperature } \\
\left({ }^{\circ} \mathrm{C}\right)\end{array}$ & $\begin{array}{c}\text { Stopping time of } \\
\text { passing the air }\end{array}$ & Absorption reading \\
\hline 400 & 60 & 32 \\
450 & 60 & 44 \\
500 & 60 & 45 \\
550 & 60 & 43 \\
600 & 60 & 43 \\
650 & 60 & 40 \\
700 & 60 & 38 \\
450 & 30 & 22 \\
500 & 30 & 28 \\
550 & 30 & 39 \\
600 & 30 & 43 \\
650 & 30 & 44 \\
700 & 30 & 44 \\
750 & 30 & 42 \\
600 & 60 & 43 \\
600 & 50 & 43 \\
600 & 40 & 43 \\
600 & 30 & 43 \\
600 & 20 & 42 \\
\hline
\end{tabular}

+ After insertation of gold trap wires into the furnace

Fig. 8 に，500，600，700 $\mathrm{C}$ に予熱された加熱炉中へ 金線捕集トラップをそう入した場合の，金線部の上昇温 度を実測した結果を例示した. 表示温度は金線捕集トラ ップ部（金量 $1.5 \mathrm{~g}$, 長さ約 $30 \mathrm{~mm}$, 直径 $5 \mathrm{~mm}$ ) の 前，後部，打よび上，中，下部の平均值である. Table Iの最も感度のよい条件と，Fig. 8 を対照して金線部の 実際温度をみると，いずれの場合も実際の加熱温度は $360 \sim 370^{\circ} \mathrm{C}$ でほぼ一致している. 以上のことから金充 てん部も実際に約 $370^{\circ} \mathrm{C}$ に達したとき通気を開始し, 吸収セルに水銀蒸気を導入することによって最もよい感 度と再現性が得られることがわかった。

\section{6 標準定量操作}

以上の実験結果から定量操作を次のように定めた・試 料分解炉と水銀捕集部の加熱炉を $500^{\circ} \mathrm{C}$ の定温度に加 熱し， $1 \mathrm{l} / \mathrm{min}$ の空気を流通させ，金線水銀捕集部をブ 


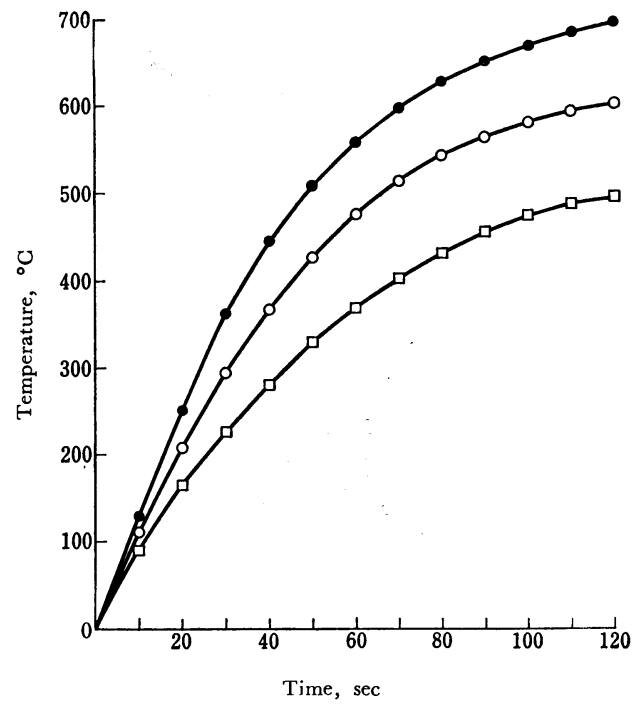

Fig. 8 Variation of the gold wire temperatures after insertation into the preheated furnace

Preheated temperature of furnace : $-\mathbf{-}-700^{\circ} \mathrm{C}$, $-\mathrm{O}-600^{\circ} \mathrm{C},-\square-500^{\circ} \mathrm{C}$

ロワーで空冷しておく．分析試料を水銀含量が分析範囲 の $100 \mathrm{ng}$ 以内になるように磁製ボート中にはかりと る. 分析試料のはいったボートを分解炉中へそう入し 3 分間加熱したのち取り出し，次に 30 秒経過したのち吸 引ポンプを止めて通気を停止する．アマルガム加熱炉を 移動させて，これまで空冷していた金線部を加熱する. 約 1 分間の加熱で金線部の温度が $370^{\circ} \mathrm{G}$ に達したとき 吸引ポンプを作動させ， $1 \mathrm{l} / \mathrm{min}$ の流量で空気とともに 水銀蒸気を吸収セルに通過させる. このとき $2537 \AA$ に おける水銀の吸光度を記録計に記録させ，ピークの高さ と水銀量の関係，すなわちあらかじめ標準試料で作成さ れた検量線より試料中の水銀含量を求める.

水銀含量が低い場合は装置の感度調節を 10 倍として, 分析範囲を 1〜 $10 \mathrm{ng}$ にすることができる. $1 \mathrm{~g}$ の試料 を用いた場合，定量限度は $1 \mathrm{ng}$ である．検量線の 1 例 を Fig. 9 に示す.

岩石・土じょう試料を日常検体として分析する場合， ときどき標準試料を間に入れて吸光度を補正・確認する 必要がある. 金線表面が污染されると水銀の捕集率が低 下する．標準試料の示す吸光度が低下した場合は，金線 を取り出し，暖めた希硝酸で数分ゆすぎ，ついで蒸留水 で洗浄後乾燥すればまた元の吸光度にもどる.

試料中に有機物が高含量の場合は加熱によってタール
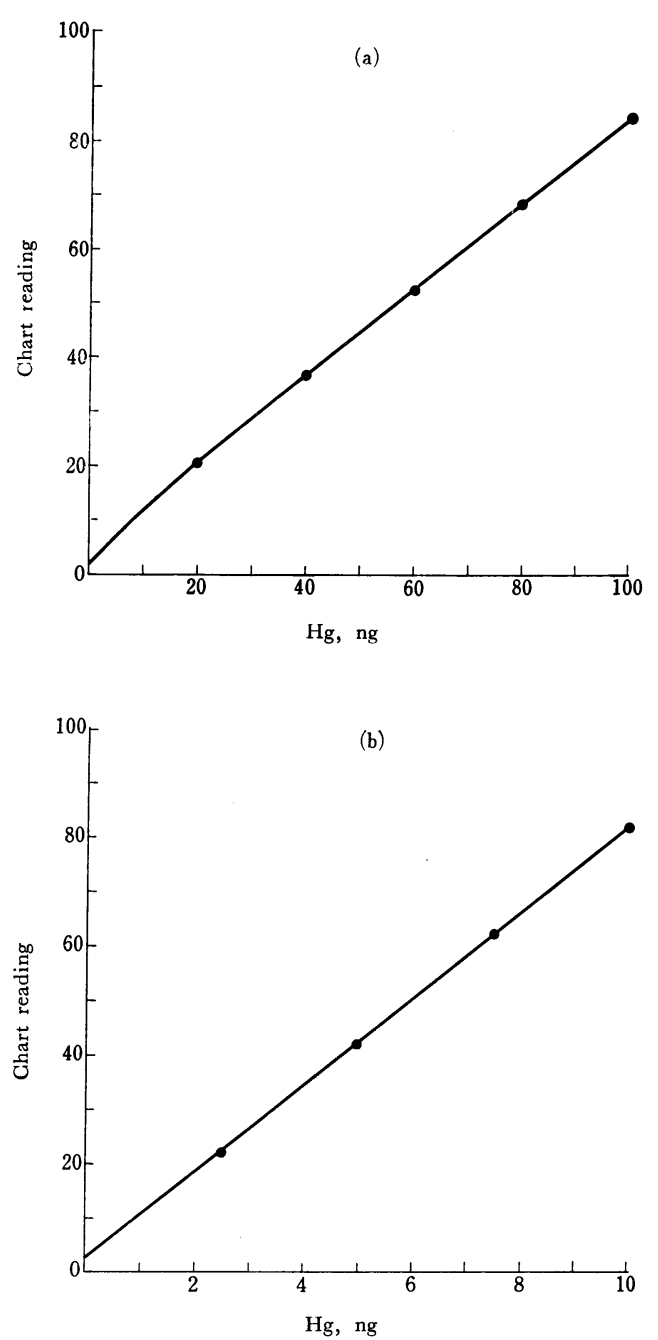

Fig. 9 Working curves

が放出され，金線捕集部を污染し，水銀捕集率を低下さ せる. また次の加熱操作で金線に付着した有機物の分解 生成気体が放出され，測定を妨害する．現在この装置で 有機物の高含量 (5\% 以上) 試料の直接分析は避けてい るが，このような場合は，湿式分解法6)を適用する必要 がある。

硫化物や硫化物を多量に含も試料を分析する場合はボ 一ト中の試料上を鉄粉でおおってから加熱すればよいと 報告されているが10)，著者らはこれについての詳しい検 討は行なわなかった.

\section{7 分析結果}

標準試料および実際の岩石・土じょう試料についての 
水銀分析結果を Table II, III に示す. Table II に示 すように, $50 \mathrm{ng}$ 水銀を含有する標準試料を用いて，1 週間にわたり 12 回くりかえし測定した結果, 变動係数 は約 4\%であった・また実際の岩石・土じょう試料でも 変動係数は Table III に示すように, 約 $5 \%$ 以内で分 析できた。

Table II Replicate analysis of standard sample during a week

\begin{tabular}{cc}
\hline \hline Mercury (ng) & Absorbance peak hight \\
\hline 50 & 32 \\
50 & 32 \\
50 & 31 \\
50 & 32 \\
50 & 34 \\
50 & 32 \\
50 & 33 \\
50 & 36 \\
50 & 32 \\
50 & 33 \\
50 & 34 \\
50 & 32 \\
\hline
\end{tabular}

Number of determination : 12 ; Standard deviation : 1.4 ; Coefficient of variation $: 4.2 \%$

Table III Precision of analysis

\begin{tabular}{|c|c|c|c|c|c|c|}
\hline \multicolumn{3}{|c|}{ Sample† } & \multirow{2}{*}{$\begin{array}{l}n \\
5\end{array}$} & \multirow{2}{*}{$\begin{array}{c}\bar{x}(\mathrm{ng}) \\
254\end{array}$} & \multirow{2}{*}{$\begin{array}{c}\sigma \\
11.9\end{array}$} & \multirow{2}{*}{$\frac{\begin{array}{l}\text { Coefficient of } \\
\text { variation }(\%)\end{array}}{4.7}$} \\
\hline Soil & & $A-7$ & & & & \\
\hline & & B-2 & 5 & 107 & 3.3 & 3.1 \\
\hline \multirow[t]{2}{*}{ Stream } & sediment & $\mathrm{K}-4$ & 5 & 402 & 10.4 & 2.6 \\
\hline & & $\mathrm{K}-8$ & 5 & 342 & 10.1 & 3.0 \\
\hline \multirow[t]{2}{*}{ Rock } & & $4 \mathrm{~L} 2 \mathrm{H}$ & 5 & 622 & 26.6 & 4.3 \\
\hline & & $6 \mathrm{~L} 5 \mathrm{H}$ & 5 & 322 & 16.0 & 5.0 \\
\hline
\end{tabular}

$\dagger$ Samples were collected from the Ryushoden mercury mine in Hokkaido (soil), Kataokagawa near the Yamato mercury mine in Nara-ken (stream sediment) and the Okuchi gold-silver mine in Kagoshima-ken (rock); $n$ : Number of determination; $\bar{x}$ : Arithmetic mean; $\sigma$ : Standard deviation

Table IV に米国地質調查所発行の 6 個の標準岩石試 料についての水銀分析結果を示した. 1〜 10 ng の超微 量成分にもかかわらず, 交献値 ${ }^{1)}$ の平均值と著者らの分 析值はよく一致しているものと思われる.

$$
5 \text { 結 言 }
$$

加熱によって容易に原子蒸気化できる水銀の特性を利 用したフレームレス 原子吸光分析装置を組み立て，岩 石・土じょうなど固体試料中の総水銀量についての最適 分析条件を検討した.

（1）岩石・土じょうなどの粉末試料を磁製ボートに 入れ， $500^{\circ} \mathrm{C}$ に予熱された電気炉中で 3 分間加熱するこ
Table IV Mercury content in U.S. G. S. standards $\dagger$

\begin{tabular}{|c|c|c|c|c|c|}
\hline Rocks & $\mathrm{Hg}(\mathrm{ng})$ & Method & Range & Average & $\begin{array}{l}\text { This study } \\
\text { (Method : AA) }\end{array}$ \\
\hline $\begin{array}{l}\text { G-2 } \\
\text { (Granite) }\end{array}$ & $\begin{array}{r}39 \\
29 \\
50 \\
40 \\
120\end{array}$ & $\left.\begin{array}{l}\mathrm{NA} \\
\mathrm{NA} \\
\mathrm{AA} \\
\mathrm{AA} \\
\mathrm{NA}\end{array}\right\}$ & $29 \sim 120$ & $\begin{array}{l}55 \\
{[42] \mathrm{c} .}\end{array}$ & 39 (9) \\
\hline $\begin{array}{l}\text { GSP-1 } \\
\text { (Granodio- } \\
\text { rite) }\end{array}$ & $\begin{array}{l}21 \\
41 \\
15 \\
17 \\
15\end{array}$ & $\left.\begin{array}{l}\text { NA } \\
\text { NA } \\
\text { AA } \\
\text { AA }\end{array}\right\}$ & $15 \sim 41$ & $\begin{array}{c}22 \\
{[17] c .}\end{array}$ & $16(4)$ \\
\hline $\begin{array}{l}\text { AGV-1 } \\
\text { (Andesite) }\end{array}$ & $\begin{array}{r}4 \\
16 \\
25 \\
26 \\
15\end{array}$ & $\left.\begin{array}{l}\mathrm{NA} \\
\mathrm{NA} \\
\mathrm{AA} \\
\mathrm{AA} \\
\mathrm{AA}\end{array}\right\}$ & $4 \sim 26$ & 17 & $6(5)$ \\
\hline $\begin{array}{l}\text { BCR-1 } \\
\text { (Basalt) }\end{array}$ & $\begin{array}{r}7 \\
4 \\
18 \\
10 \\
5\end{array}$ & $\left.\begin{array}{l}\mathrm{NA} \\
\mathrm{NA} \\
\mathrm{AA} \\
\mathrm{AA} \\
\mathrm{AA}\end{array}\right\}$ & $4 \sim 18$ & 9 & $7(6)$ \\
\hline $\begin{array}{l}\text { PCG-1 } \\
\text { (Peridotite) }\end{array}$ & $\begin{array}{r}4 \\
4 \\
5 \\
11 \\
10\end{array}$ & $\left.\begin{array}{l}\mathrm{NA} \\
\mathrm{NA} \\
\mathrm{AA} \\
\mathrm{AA} \\
\mathrm{AA}\end{array}\right\}$ & $4 \sim 11$ & 7 & $4(4)$ \\
\hline $\begin{array}{l}\text { DTS-1 } \\
\text { (Dunite) }\end{array}$ & $\begin{array}{r}4 \\
6 \\
12 \\
10 \\
8\end{array}$ & $\left.\begin{array}{l}\mathrm{NA} \\
\mathrm{NA} \\
\mathrm{AA} \\
\mathrm{AA} \\
\mathrm{AA}\end{array}\right\}$ & $4 \sim 12$ & 8 & $9(6)$ \\
\hline
\end{tabular}

$\dagger$ Data were cited from U. S. Geol. Surv. Prof. Paper 713 (1970) ${ }^{11}$ except this study; AA : Atomic absorption spectrophotometry; NA : Neutron activation analysis; [ ]c. : Consensus mean, arithmetic mean of the values within $2 \sigma ;():$ Number of determination

とにより試料中の水銀を完全に原子化できる.

（2）妨害成分は金線 $1.5 \mathrm{~g}$ （直径 80 ミロン） を充てんした捕集部で完全に分離することができる. Vaughn ら ${ }^{10}$ は $2 \mathrm{~mm} \times 2 \mathrm{~mm}$, 厚さ $1 / 2 \mathrm{~mm}$ の金の薄 片， $15 \mathrm{~g}$ を水銀の捕集に用いている. 著者らは水銀の捕 集に効果的な直径 80 ミクロンの金線フイルターを用い ることによって金量を $1 / 10$ に減らすことができた.

（3）アマルガムとして捕集された水銀を原子蒸気化 する加熱温度と, 加熱によって放出された水銀蒸気を吸 収セルへ送る通気の開始時間は感度と再現性に大きな影 響を与える．著者らは金線捕集部の温度が $370^{\circ} \mathrm{C}$ に達 したとき，通気を開始する測定方法を適用することによ って目的精度を得ることができた。

（4）本装置によって岩石・土じょう試料中の総水銀 を試料の採取量を調節することによって，1〜1000 ng 水銀の範囲で， 1 試料を 6 分以内に定量することがで きる. 定量限度は, 試料 $1 \mathrm{~g}$ を用いた場合 $1 \mathrm{ng}$ であ る. $\left(\begin{array}{l}1971 \text { 年 } 11 \text { 月, 第 } 7 \text { 回応用スペクト } \\ \text { ロメトリー東京討論会において講演 }\end{array}\right)$ 


\section{文献}

1) Mercury in the environment: U. S. Geol. Surv. Prof. Paper 713 (1970).

2) F. N. Ward, E. H. Bailey : Am. Inst. Min., and Pet. Eng. Trans., 217, 343 (1960).

3) 岸本交男, 加藤甲壬 : 鉱山地質, 13，243 (1963).

4) W. Slavin : "Atomic Absorption Spectroscopy", (1968), (Interscience Publishers, New York).

5) H. Brandenberger, H. Bader : Atomic Absorption News Letter, 6, No. 5, 101 (1967).

6) W. R. Hatch, W. L. Ott : Anal. Chem., 40, 2085 (1968).

7) G. H. James, J. S. Webb : Trans. Inst. Min. Metall, 73, 633 (1964).

8) A. R. Barringer : Appl. Earth Sci., 75, B 120 (1966).

9) S. H. Williston : Eng. Min. J., 165, No. 5, 98 (1964).

10) W. W. Vaughn, J. H. McCarthy, Jr. : U. S. Geol. Surv. Prof. Paper, 501-D, 123 (1964).

11) W. W. Vaughn : U. S. Geol. Surv. Cir., 540, 1 (1967).

12）加藤甲壬：地質調月報，22，437（1971）.

$$
\text { 它 }
$$

Determination of trace amount of mercury in rocks and soils by a flameless atomic absorption spectrophotometry. Komi Kato, Atsushi ANDO* and Toshihiko Kisнiмото** (*Geological Survey of Japan, Kawasaki-shi, Kanagawa-ken; **Nippon Jarrell Ash Co. Ltd., Fushimi-ku, Kyoto-shi)

New device for the determination of trace amount of mercury in rocks and soils as developed for use in our labaratory is a modification of the method reported by Vaughn and McCarthy.

In our system, sample taken in a porcelain boat is heated with electric furnace and the mercury is vapo- rized and carried up to the gold trap wire by an air stream. Only mercury is selectively trapped on the gold wire making amalgam, and decomposition gases resulted from burning of sulfides and organic materials, and water pass on out the system through the part of gold trap and to the exhaust pipe.

After removal of interfering gases, an air stream is stopped at once, the mercury trapped on the gold wire is vaporized by heating the gold with electric furnace, and the resulting mercury vapor is carried into the absorption cell by starting the flowtation of air stream. A thermocouple equipped on the gold trap control the starting time of air flowtation.

As a result of traverse of the mercury vapor through the absorption cell, atomic absorption signal of mercury at $2537 \AA$ sharply increase to a maximum and quickly return to zero.

The gold trap is allowed to cool to room temperature with an air blow and set up to the another sample.

A number of parameters have been investigated which affect the determination of mercury in this system.

Mercury in rocks and soils is completely vaporized as monoatomic gas by heating with preheated electric furnace at $500^{\circ} \mathrm{C}$, within 3 minutes. $80 \mu \phi$ pure gold wire used for trapping the mercury was effective. Only 1.5 gram is an adequate amount in the analytical range $1 \sim 100 \mathrm{ng}$ of the mercury. About ten times larger square plates of gold have been used by early investigators.

Adjusting the weight of sample taken, $1 \sim 1000 \mathrm{ng}$ of the mercury in rocks and soils has been determined routinely. Coefficient of variation is about $5 \%$. Detection limit using 1 gram sample is $1 \mathrm{ng}$. Time required for the analysis of one sample is within 6 minutes.

(Received Feb. 9, 1972) 